DOE/RL-97-40

\title{
FY 1996 Cost Savings Report
}

Date Published

April 1997

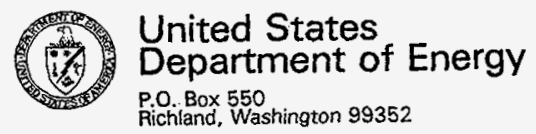

Approved for Public Release 


\section{LEGAL DISCLAIMER}

This report was prepared as an account of work sponsored by an agency of the United States Government. Neither the United States Government nor any agency thereof, nor any of their employees, nor any of their contractors, subcontractors or their employees, makes any warranty, express or implied, or assumes any legal liability or responsibility for the accuracy, completeness; or any third party's use or the results of such use of any information, apparatus, product, or process disclosed, or represents that its use would not infringe privately owned rights. Reference herein to any specific commercial product, process, or service by trade name, trademark, manufacturer, or otherwise, does not necessarily constitute or imply its endorsement, recommendation, or favoring by the United States Government or any agency thereof or its contractors or subcontractors. The views and opinions of authors expressed herein do not necessarily state or reflect those of the United States Government or any agency thereof.

This report has been reproduced from the best available copy. Avallable in paper copy and microfiche.

Available to the U.S. Department of Energy and its contractors from

Office of Scientific and Technical Information

P.O. Box 62

Oak Ridge, TN 37831

(615) $576-8401$

Available to the public from the U.S. Department of Commerce National Technical information Service

$\mathbf{5 2 8 5}$ Port Royal Road

Springfield, VA 22161

(703) $487-4650$

Printed in the United Stotes of Americs

DISCLM-1.CHP (1-91) 


\section{FY 1996 COST SAVINGS REPORT}

Cost savings are an integral part of Hanford site operations. Congressional actions towards establishing a balanced budget have resulted in reductions to funding for all federal agencies, including the Department of Energy (DOE) Environmental Management (EM) cleanup mission. In September 1994 the DOE - Richland Operations Office (RL) approved the FY 1995 multi-year baseline that included a cost estimate of $\$ 1.9$ billion for FY 1996 . However, Congress only appropriated $\$ 1.3$ billion for that year. The shortfall of $\$ 600$ million resulted in a significant challenge to accomplish the required workscope. Therefore, $\mathrm{RL}$ initiated an aggressive cost savings program to eliminate the shortfall by deleting workscope that was unnecessary and performing the remaining workscope more efficiently.

\section{BACKGROUND}

RL began tracking and reporting cost savings in FY 1994 after renegotiation of the Tri-Party Agreement (TPA). The signatories to the TPA executed an amendment called the "Cost and Management Efficiency Initiative" (CEI) that committed to savings of $\$ 1$ billion over a five year period (1994-1998). In May 1995 RL participated in a workshop with $H Q$ and stakeholders and committed to an additional $\$ 1.3$ billion in savings, for a total of $\$ 2.3$ billion over a four year period (FY 1995-1998). These commitments were documented in the "St. Louis Blueprint for Action and Cost Control at Hanford" (St. Louis Blueprint). RL initiated numerous cost savings initiatives in FY 1994 and 1995 and reported a total of $\$ 2.7$ billion of savings for FY $1995-1998$ in the June 1996 Hanford Cost Savings Plan (HCSP). This plan was prepared by the Contract Finance \& Review Division (CFR), reporting to the RL Chief Financial Officer (CFO), and accepted by $\mathrm{HQ}$ as closure of the St. Louis Blueprint cost savings commitment. CFR then briefed the Dollars \& Sense Committee of the Hanford Advisory Board $(\mathrm{HAB})$ on the HCSP.

\section{SAVINGS}

The FY 1996 savings baseline was the $\$ 1.9$ billion cost estimate for FY 1996 from the FY 1995 multi-year baseline. FY 1995 savings initiatives had a $\$ 300$ million positive impact on FY 1996 and reduced the FY 1996 shortfall from $\$ 600$ million to $\$ 300$ million. The revised FY 1996 baseline, therefore, was $\$ 1.6$ billion. 
$\mathrm{RL}$ initiated baseline planning actions (including deletions, deferrals, transfers, and additions) during the FY 1996 multi-year baseline development process to match workscope and anticipated funding and identified $\$ 205$ million of workscope deletions. CFR then reviewed over 200 cost baseline change requests during $F Y 1996$ and documented an additional \$95 million of FY 1996 cost savings. This included $\$ 73$ million of workscope deletions and $\$ 22$ million of efficiencies. Total savings as a result of FY 1996 initiatives, including baseline planning actions and current year initiatives, were $\$ 300$ million.

\section{FY 1996 Savings Summary}

$\$$ in millions

\begin{tabular}{|lr|}
\hline FY96 Cost Estimate from FY95 MYPP & 1.9 \\
\hline Effect of FY95 savings initiatives & $(0.3)$ \\
Revised FY96 Baseline & 1.6 \\
\hline FY96 Baseline Planning Actions (workscope deletions) & $(0.2)$ \\
Approved FY96 MYWP & 1.4 \\
\hline Effect of FY96 savings initiatives & $(0.1)$ \\
FY 1996 Funding & 1.3 \\
\hline
\end{tabular}

\section{Savings By Contractor}

\begin{tabular}{|c|rccccc|}
\hline \multicolumn{7}{|c|}{ Dollars in Millions } \\
\hline \multirow{2}{*}{$\begin{array}{c}\text { Contractorf } \\
\text { DOE }\end{array}$} & $\begin{array}{c}\text { Baseline Planning } \\
\text { Savings }\end{array}$ & $\begin{array}{c}\text { Actions/Workscope } \\
\text { Deletions }\end{array}$ & $\begin{array}{c}\text { Current Year } \\
\text { Deletions }\end{array}$ & $\begin{array}{c}\text { Current Year } \\
\text { Efficiencies }\end{array}$ & Total \\
\hline WHC & $68 \%$ & $(\$ 136)$ & $(\$ 54)$ & $(\$ 13)$ & $(\$ 203)$ \\
BHI & $20 \%$ & $(\$ 35)$ & $(\$ 15)$ & $(\$ 9)$ & $(\$ 59)$ \\
PNNL & $6 \%$ & $(\$ 13)$ & $(\$ 4)$ & $\$ 0$ & $(\$ 17)$ \\
$R L$ & $7 \%$ & $(\$ 21)$ & $\$ 0$ & $\$ 0$ & $(\$ 21)$ \\
Total & $100 \%$ & $(\$ 205)$ & $(\$ 73)$ & $(\$ 22)$ & $(\$ 300)$ \\
\cline { 2 - 7 }
\end{tabular}




\section{SAVINGS VERIFICATION}

Review of change requests. The review of the baseline change requests was an integral part of the savings process. CFR reviewed each of the cost baseline change requests to determine:

(1) The impact of the change request on the project baseline and the validity of the change, and

(2) The nature of the action(s), e.g., deletion, deferral. Many change requests contained multiple actions. CFR reviewed the information on a quarterly basis with the RL projects.

\section{EXAMPLES OF BASELINE CHANGES DURING FY 1996}

\section{Current Year Workscope Deletions}

- Reengineered \& redefined needs of Enhanced RMW Storage Project. De-scope resulted in lower estimate $(\$ 7 \mathrm{M})$

- Re-scoped 300 Area Process Sewer Piping System Upgrade Project to use slip lining instead of installing a new piping system $(\$ 3 \mathrm{M})$

- Implemented final activity based cost estimate changes at PFP (reengineering activities) $(\$ 3 \mathrm{M})$

- Combined two ground water treatment systems into one (\$2M)

- Rebaselined RCRA and Operating Monitoring, resulting in lower estimate (\$3M)

\section{Workscope Deferrals:}

- Waste characterization workscope (\$3M) and characterization study strategy (\$2M)

- 300 Area remedial actions $(\$ 2 M)$

- 100-NPL REDOX treatment (\$1M)

- 100-Area Group II Remedial Design (\$1M)

- Cleanup and terminal cleanout activities associated with Segment \#5 in the 234-5Z Building $(\$ 1 M)$

\section{Workscope Accelerations (from outyears):}

- Supported path forward for removing fuel from the $K$ Basins $(\$ 1 M)$

- Implemented site characterization activities on LLW and HLW projects (\$1M)

- 100-KR-4 Operable Unit activities (\$3M)

- Early arrival of Interim Storage Casks $(\$ 3 M)$

- Contract support for development of Tank Characterization Reports (\$1M) 


\section{Current Year Workscope additions (emergent workscope):}

- Maintained operation of the PNNL Analytical Chemistry Laboratory as a backup to the 222-S Lab (\$2M)

- Implemented workscope to support a sound safety authorization basis $(\$ 1 \mathrm{M})$

- Improved analysis to support FSAR that is compliant with DOE orders (\$3M)

- Expanded Mission Direction Document and added Ten Year Plan coordination (\$.3M)

- Completed supplemental study on Cesium capsules (\$1M)

Use of PTS system for efficiency savings. CFR used the EM Progress Tracking System (PTS) data, as shown in the EM Performance Summary report, to identify the expense cost variance. The cost variance is calculated by subtracting the actual cost of work performed (ACWP) from the budgeted cost of work performed (BCWP). A positive cost variance results when the actual cost of the work performed is less than budgeted, i.e., the work was performed efficiently.

Use of PTS system to test system integrity. CFR developed a revised baseline for each project at year end that reflected the impacts of all approved cost baseline change requests. CFR then compared this revised baseline to the baseline reported in the year-end EM Performance Summary report to verify that all change requests were reflected in the PTS system. This ensured that savings were not duplicated.

External Validation. The St. Louis Blueprint included a commitment to have the FY 1995 savings validated by an independent party to increase EM's credibility in controlling costs at Hanford. DOE recognized that the FY 1995 results would have high visibility due to the savings incentive clause in the WHC contract. RL contracted with Arthur Andersen LLP to perform this work. Arthur Andersen staff reviewed both the savings verification process and the reported savings, concluding that both were reasonable.

$R L$ concluded that it would not be cost-effective to have an external validation of FY 1996 savings because:

- The FY 1996 WHC contract did not include a cost savings incentive clause, and there were not any HQ or stakeholders' requirements for an independent review of the savings.

- CFR is independent of the organizations responsible for making and maintaining changes to the baseline and continued to use the same process to verify savings that was used in FY 1995.

- The CFR staff is skilled in analytical and auditing techniques, performs other independent reviews for the CFO \& RL Manager and serves as the primary $R L$ interface with the Inspector General (IG) and General Accounting Office (GAO). 


\section{FY 1997 COST SAVINGS PROGRAM}

$H Q$ has not assigned a savings target to $R L$ and the Fluor Daniel Hanford (FDH) contract does not contain a cost savings incentive clause for FY 1997. However, HQ has recommended that RL continue to track cost savings and be prepared to report results at year end. CFR will continue to use the same process for verifying and reporting savings in FY 1997.

The baseline for FY 1997 savings is the $\$ 1.3$ billion cost estimate included in the FY 1996 multi-year baseline. RL is in the process of fully documenting the impacts of FY 1996 change requests on the FY 1997 baseline and the additional baseline planning actions that were necessary to match FY 1997 workscope and funding. Additional workscope deletions and efficiency savings achieved during FY 1997 will also be tracked and verified. 